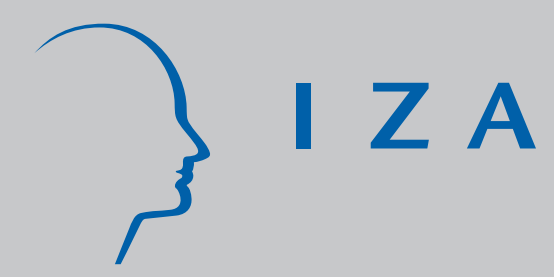

IZA DP No. 345

Survival, Growth, and Interfirm Collaboration of Start-Up Companies in High-Technology Industries: A Case Study of Upper Bavaria

J ohannes Hampe

Martin Steininger

August 2001 


\title{
Survival, Growth, and Interfirm Collaboration of Start-Up Companies in High-Technology Industries: A Case Study of Upper Bavaria
}

\author{
Johannes Hampe \\ University of Munich \\ Martin Steininger \\ Technical University of Munich \\ Discussion Paper No. 345 \\ August 2001 \\ IZA \\ P.O. Box 7240 \\ D-53072 Bonn \\ Germany \\ Tel.: +49-228-3894-0 \\ Fax: +49-228-3894-210 \\ Email: iza@iza.org
}

This Discussion Paper is issued within the framework of IZA's research area The Future of Work. Any opinions expressed here are those of the author(s) and not those of the institute. Research disseminated by IZA may include views on policy, but the institute itself takes no institutional policy positions.

The Institute for the Study of Labor (IZA) in Bonn is a local and virtual international research center and a place of communication between science, politics and business. IZA is an independent, nonprofit limited liability company (Gesellschaft mit beschränkter Haftung) supported by the Deutsche Post AG. The center is associated with the University of Bonn and offers a stimulating research environment through its research networks, research support, and visitors and doctoral programs. IZA engages in (i) original and internationally competitive research in all fields of labor economics, (ii) development of policy concepts, and (iii) dissemination of research results and concepts to the interested public. The current research program deals with (1) mobility and flexibility of labor markets, (2) internationalization of labor markets and European integration, (3) the welfare state and labor markets, (4) labor markets in transition, (5) the future of work, (6) project evaluation and (7) general labor economics.

IZA Discussion Papers often represent preliminary work and are circulated to encourage discussion. Citation of such a paper should account for its provisional character. 
IZA Discussion Paper No. 345

August 2001

\title{
ABSTRACT \\ Survival, Growth, and Interfirm Collaboration of Start-Up Companies in High-Technology Industries: A Case Study of Upper Bavaria
}

Our analysis of the survival of firms leads to the important result that the hypotheses about differences between various industries in the life duration of new firms and about the importance of the region of location for the probability of survival are confirmed. Many more enterprises are founded in the service sector than in manufacturing, but also many more of these start-ups die. The probable life duration in agglomeration areas is in total greater than in rural areas. The analysis of the determinants of the hazard rates of firms confirmed the additional hypothesis that a larger number of employees at the time of foundation and the legal form of the limited company reduce the risk of exit.

The growth of employment in firms interviewed by us shows a similar sectoral and regional differentiation as the life duration. The survey found that sectors with a greater proportion of cooperating firms have a greater growth rate. The innovation activities however do hardly differ between the analysed high-tech industries. Cooperation between start-up firms can be interpreted as a kind of mutual assistence which results predominantly from personal contacts. The personal networks which developed from the environment of the entrepreneurs and according to specific sector conditions should not be treated as equivalent to innovation networks for which our analysis does not find any empirical hint.

JEL Classification: $\quad$ C41, J2, J60, L10, R30

Keywords: Life duration, labor market policy, start-up, high-tech firms, cooperation

\author{
Martin Steininger \\ Technical University of Munich \\ Arcisstr. 21 \\ 80333 München \\ Germany \\ Tel.: +49 89-289-28672 \\ Fax: +49 89-289-25214 \\ Email: Martin.Steininger@vwl.wiso.tu-muenchen.de
}




\section{Introduction}

The theory of the firm is a central part of the (neo)classical microeconomic analysis. In the models of competitive markets, contestable markets and monopolistic competition, entries of new enterprises and exits of old enterprises change market structure and performance and are an important factor in reaching the long-term equilibrium in an industry. "Turnover processes are ubiquitous among plants and firms classified to an industry. They are also stable, explicable, and can be embraced within the traditional thinking based on market-equilibrium models that underlies the bulk of empirical research in industrial organisation." (Caves, 1998, p. 1975).

Working on the basis of the models conditions for entries of new enterprises and exits from a market are examined. The micro-economic and industrial economic text-books are restricted to the handling of cases in which new enterprises fight for the entry on a given market with already existing firms. Here the lower costs of the enterprises which are already in the market obstruct the entry of new enterprises. "A barrier to entry may be defined as a cost of producing (at some or every rate of output) which must be borne by a firm which seeks to enter an industry but is not borne by firms already in the industry" (Stigler, 1968, p. 67).

Most of the German contributions to the research on the foundation of a company are quantitative studies in business economics in which empirical determinants of foundations within an ad hoc developed reference framework are described. The transaction cost theory of Coase (1953) and its improvement by Williamson (1975 and 1989) supply a theoretical instrument to explain the foundation of firms. On this basis Picot, Laub and Schneider (1989) developed a theory which tries to explain the foundation of a firm. In this approach, too, the strong concentration on cost-theoretical interdependencies causes difficulties in explaining the genesis of firms, which develop completely (technically) new goods and (possibly) form new markets. In the long run however, these foundations due to technological change are what advances the structural change and development of an economy.

"Many of the persistently most profitable firms in the United States are companies which came into existence along with the products with which they are most closely associated, e.g. Kodak, Gillette, Kellogg's, Gerber, Campbell Soup, Polaroid, Coca Cola, Wrigley, and Hoover" (Mueller, 1991, p. 9). For such new enterprises, cost considerations are of smaller importance since they do not have to fight for market entry with competitors who are already 
present on the market. However, the same holds true for established firms that are successful on new markets with the continuing development of new products or even the complete conversion of their product program. Traditional (conglomerate) companies (like Siemens or Nokia) diversified into new markets, as for example microelectronics and telecommuniction. Some old enterprises from the basic industry (above all the steel and mining sector) have switched to new products and new markets, especially in the telecommunication sector (e.g. Mannesmann now taken over by Vodafone-Airtouch) or established themselves in a different market like tourism (e.g. Preussag by taking over Hapag-Lloyd, TUI and Thomson Travel).

The relationship will be treated predominantly in the context of the product cycle models, with which regional developments are also explained (Markusen, 1985). On the one hand the longer a firm is already existing in the market, it learns to decrease costs even more and increase efficiency. On the other hand, high profits can be obtained in the first phase of the product cycle but the danger of failure is great, too. Empirical investigations have already been able to show the influence of the product cycle's phase in which the firm entered the market on its probability of survival (Agarwal, Gort, 1996).

The research work reported here deals with the more pragmatic economic-political questions, and will neither try to prepare a general micro-economic theory of firm formation nor deal with the specific theories which try to explain the development of high-tech enterprises which enter the market in the first phase of the product cycle or follow basic innovations ,in swarms“ (Schumpeter, 1952) and form new industries. Our contribution is restricted to the analysis of the importance of new high-tech enterprises for structural change and the growth of employment in a region and to establishing factors for the development, survival and growth of these new firms. Since we regard only foundations within the hightech area, we cannot predict differences in the founding, innovative and cooperative behavior of firms in high tech compared with other industries.

We will first describe the data sources, which we had at our disposal and detail as well the used definitions of high-tech firms, entries and exits. The empirical analysis of survival probabilities of newly founded enterprises and their determinants follows. Then comes the part of the work for which the data had to be extracted from a survey and which deals with the innovative and cooperative behavior of new firms. Because of the limited space we will restrict ourselves to the description of the empirical results of the survey with regard to the cooperative and innovative behavior and development of newly founded firms. 


\section{Data Sources and Definitions}

The data sources of this paper are the address data set of the Chamber of Industry and Commerce for Munich and Upper Bavaria about the registrations of businesses in selected high-tech industries and a questioning of some firms out of these addresses. The data set of the Chamber of Industry and Commerce serves for the registration of potential members. Irrespective of the notification of the chamber fees, everybody having registered a business receives a salutatory writing from the Chamber of Industry and Commerce as well as later the chamber's journal four times a year. Therefore there is (at least) a constant examination of the adresses set.

The disadvantages of the record of businesses at the Chamber of Industry and Commerce for the purpose of analysing the formation of firms have already been discussed frequently, particularly in context with the research work of the Institute for Sociology at the University of Munich which uses the same data set as we did (Brüderl et al., 1992). New start-ups cannot be separated from the advertised takeovers and shifts of existing firms. But since we put in our analysis special attention on the regional effects, all firm entries in a region form in our opinion a suitable starting point. On the basis of the traditional model of a market equilibrium all changes in the structure of companies in a region should in the long run result in an adjustment to the optimal allocation of factors of production. It has to be considered, however, that the registration of a trade does not necessarily mean that it is exercised. Pseudo registrations of business and the existence of second jobs cannot be detected. They are assumed particularly with the small businesses. Additionally all managing partners are notifiable in partnerships so that with non-contemporaneous notification an allocation to the foundation of the same firm is not ensured. Because of the factors mentioned above a certain overestimation of foundations is probable. However in our opinion the error rate should not be large enough, - at least for the chosen high tech sectors -, to distort the statistical analysis systematically. A lot of the companies we interviewed in our survey which at the time of foundation often had no employee except for the founder himself have developed to a „real“ firm.

For many of the newest studies about foundation of firms, the data of the Chamber of Industry and Commerce does not form the data basis but the start-up panel (West) of the Zentrum für Europäische Wirtschaftsforschung (ZEW) based upon the CREDITREFORM 
data record (see Nerlinger 1998). CREDITREFORM records all registrations in the register of companies, otherwise it only investigates if there are inquiries about the creditworthiness of an enterprise. Thus on the one hand pseudo registrations of businesses are probably excluded. On the other hand it can safely be assumed that certain foundations are underevaluated. According to Harhoff/Steil this underestimation concerns "... primarily smallest businesses (so-called small traders)." (Harhoff and Steil 1997, p. 16)

The following data of he register of trade were taken by us from the data of the Chamber of Industry and Commerce:

Firm name and legal form of the company.

The location of the firm, available as the address with postal zip code. The addresses were assigned to the four planning regions, which form the chamber and governmental district, and to different structural types of regions, defined by the Federal Research Institute for Regional Geography and Regional Planning (BfLR).

Year, month, day of the registration of business, provided that this company was registered before 01.01.1985 and still existing afterwards or that it was newly registered after 01.01.1985. In the following we constitute this date as the date of foundation.

Year, month and day of exit of trade or rest of business activity. We used the exit of trade or an earlier date of rest as the date of abandonment.

The size of firm which assigns it to one of twelve size classes, namely:

0 employee, 1-3 employees, 4-6, 7-9, 10-19, 20-49, 50-99, 100-199, 200-499, 500-999,10004999, 5000-9999, 10000 and more employees.

The classification of firms into the sectors of the economy, according to the five-digit classification of industrial sectors of the economy of 1993 (WZ 93) of the Federal Statistical Office.

We have concentrated our empirical analyses on firms in the high-tech sector. A technology-intensive industry is defined as a high-tech industry, if certain industry specific input or output indicators are satisfied which are usually used for differentiation, e.g. expenditures in Research and Development $(R \& D)$, employees in $R \& D$ or patents, turnover shares with product or process innovation. In the present investigation we have followed the recently often applied separation of technology-intensive sectors (see Nerlinger 1998), based on an arrangement of „technology-intensive“ goods by OECD (Gehrke, Grupp 1994). Those branches of trades are named as (cutting-edge) high technology which have an intensity in $R \& D$ (expenditures in $R \& D$ referring to the turnover) of over 8.5 percent. These sectors are registerd with five-digits in the classification of industry (WZ 79). 
The classification of the industries in the entire data set which we used to analyse the probability of survival of firms was done by the Chamber of Industry and Commerce. During the analysis of the questionnaire this allocation was corrected by us according to the enterprises' responses referring to the products manufactured by them. This led in particular to a shift of a small number of firms from the manufacturing to the service sector.

The following industries were the ones with the most advanced technology in manufacturing (Table 2.1.) (under neglect of 23.30.0 "Nuclear material industry”):

Table 2.1. High-tech sectors of economy: manufacturing

\begin{tabular}{|c|c|}
\hline WZ 93 & Industry \\
\hline 24.4 & Pharmaceutical products \\
\hline 24.6 & Miscellaneous chemicals ${ }^{1}$ \\
\hline 30.020 & Electronic computers \\
\hline 33.1 & Surgical, medical and dental instruments \\
\hline 33.2 & $\begin{array}{l}\text { Engineering, laboratory instruments, scientific and research instruments, } \\
\text { measuring and controlling instruments }\end{array}$ \\
\hline 33.40 .2 & Optical instruments and lenses \\
\hline 33.40 .3 & Photographic equipment and supplies ${ }^{2}$ \\
\hline 35.3 & Aerospace equipment manufacture \\
\hline
\end{tabular}

Note: 1) This industry is counted among the sectors of high-order technology by Gehrke/Grupp, but was included by us because of some - in our discretion - registered high-tech products among 24.6 "Miscellaneous Chemicals."

2) This industry is counted among high-order technology by Gehrke/Grupp.

Apart from these industrial sectors in manufacturing we considered selected technologyintensive service sectors (Table 2.2.) just like in other available research studies (Nerlinger 1998). According to WZ 93 it concerns the following industries: 
Table 2.2. High-tech sectors of economy: services

\begin{tabular}{cl}
\hline WZ 93 & Industry \\
\hline \hline 72 & Computer and data processing services \\
73 & Research and development laboratories \\
74.2 & Engineering services $\quad\}$ combined to one industry $(74.2 / 74.3)$ \\
74.3 & Surveying services \\
74.4 & Advertisement $^{1}$ \\
\hline
\end{tabular}

Note: 1) This is not a technology-intensive industry which was nevertheless included by us for comparison.

\section{Variation in Survival and Exit across High Tech Industries}

\subsection{The Basic Facts}

The four planning regions located in the area under investigation Upper Bavaria, differ mostly in the type of region, the total population, the rate of employment, and the economic structure, because Upper Bavaria consists of an agglomeration area but also an urbanized area and two rural regions (see Table A1 in the appendix). New firms are founded as two or three times as often in the region of Munich as in others but are closed about just as frequently. This high correlation between entry and exit rates is already mentioned in some other studies (e.g. Dunne, Samuelson 1988). In the service sector this ratio between entries and exits since 1985 varies in the diverse regions between 3.5 and 3.1. In manufacturing this ratio differs much more depending on the sector, in fact between 4.1 and 2.6 (see Table A2 in the appendix). Table A3 and A4 (in the appendix) and Fig. 3.1. and 3.2. show great differences between manufacturing and the service sector in the relation between the entries and exits of start-ups firms (since 1985) and exits out of the stock of firms founded before 1985. While the formations in manufacturing led to a clear increase of firm numbers in the end of the 80's/at the beginning of the 90's, exits clearly outweighted the new entries from the middle of the 90’s on. 


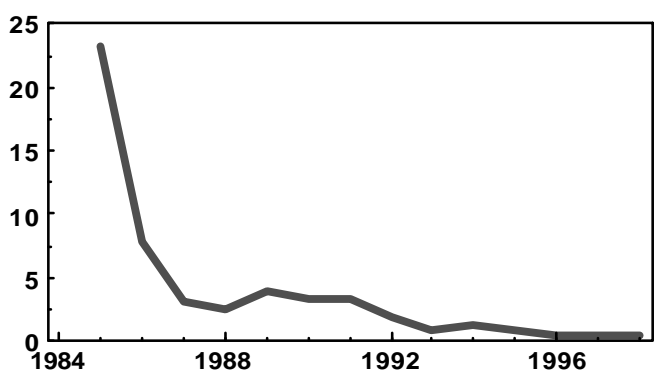

Fig. 3.1 Ratio entry to exit (manufacturing sector), per year

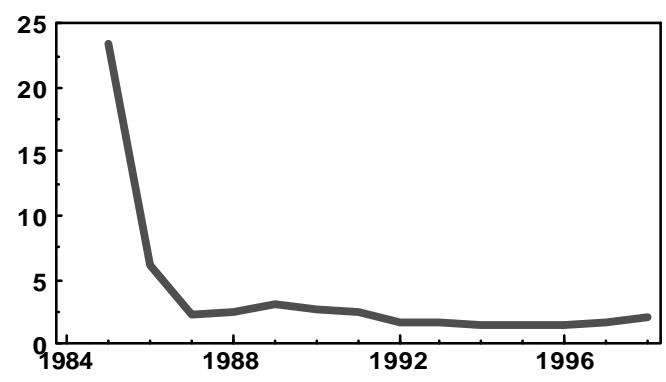

Fig. 3.2 Ratio entry to exit (service sector), per year

Only due to the large number of start-ups in the service sector there is an increase in the total number of firms despite a continuous exit rate from the stock of enterprises founded before 1985 (Fig. 3.3.).

\subsection{Longitudinal Aspects of Survival and Exit of High Technology Firms}

Kiefer (1988) describes very clearly the necessity of developing statistical methods in order to analyze duration of certain appearances. Since not all firms die before the end of the observation period and the determinants of the length of

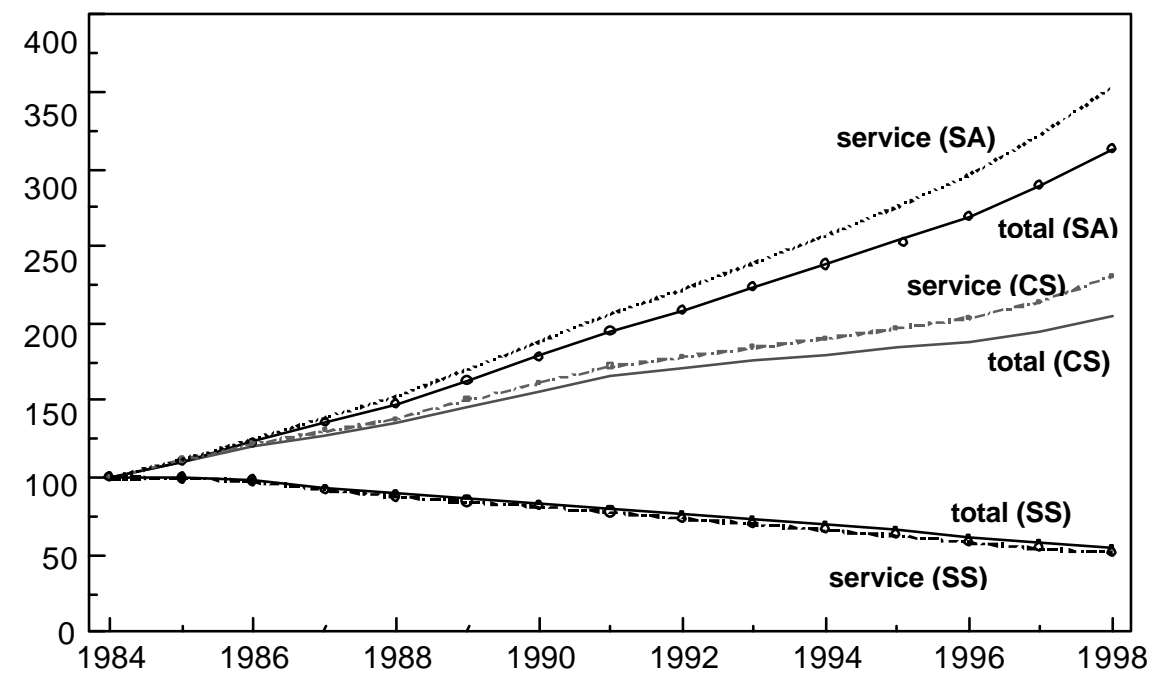

Fig 3.3 Number of high-tech firms (total, service sector) in Upper Bavaria: current stock (CS), stock without exits (SA) and stock without start-ups (SS) $(1984=100)$ 
life can change during the life span, one needs another method for the measurement of life duration than simply the number of months. The conditional probability that a firm continues existing if it already has survived a certain time (e.g. one year) is of interest. The point at which a certain event occurs (here the firm exit) is, in accordance to assumption, subject to a certain probability distribution. Apart from the survival function the hazard rate function indicating the risk of a firm after a certain duration of life to exit at a given point of time is used.

Related to our data set in form of life duration - measured in months - of the more than 7700 newly established firms, that died during the period of investigation (1985-1998) or are still alive, we used the standard method for estimating a survival function, the product limits estimator proposed by Kaplan and Meier, because ,the product limits estimator provides an efficient means of estimating the survival function for right-censored data." (Klein, Moeschberger 1997, p. 85). Survival functions were calculated separately for subsets of the data. $^{1}$

Fig. 3.4. shows that the probability of a company in manufacturing to survive a certain number of months is always greater than the probability of a firm in the service sector. The probability of a firm in manufacturing to live longer than 100 months for example is about 67 percent, in the service sector only approximately 59 percent. Fig. 3.5. shows a clearly higher probability of survival of the legal form limited liability company $(\mathrm{GmbH})$ in comparison to companies of all other legal forms. Here, however, also the sectoral affiliation has an effect. Fig. 3.6. shows a duration of life, which is longer on average in the region of Munich than in other regions. The probability of survival in the city of Munich, however, is below the average (Fig. 3.7.).

\footnotetext{
${ }^{1}$ All estimations in this study were performed with the aid of "Stata Statistical Software, Release 6.0".
} 


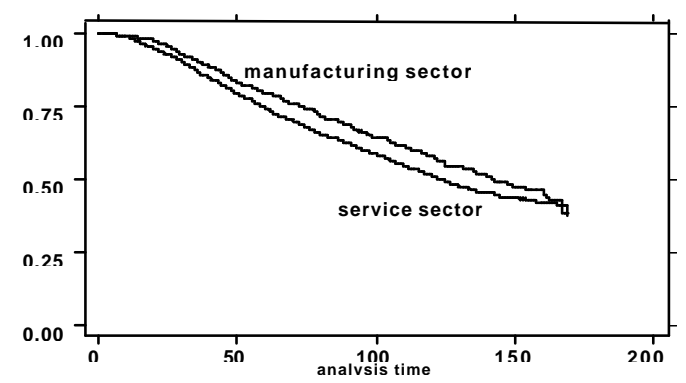

Fig. 3.4 Survival estimates, manufacturing vs. service sector

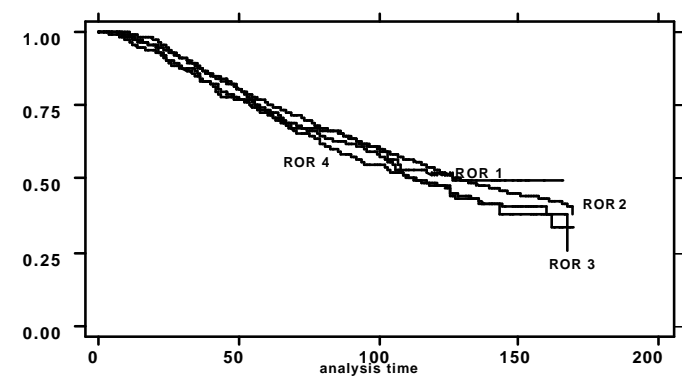

Fig. 3.6 Survival estimates, by regions

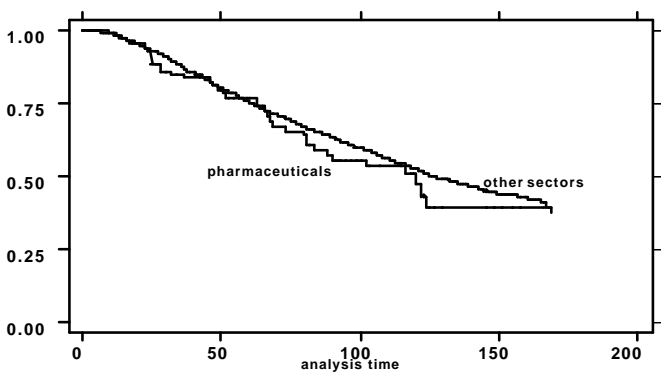

Fig. 3.8 Survival estimates, by pharmaceuticals vs. other sectors

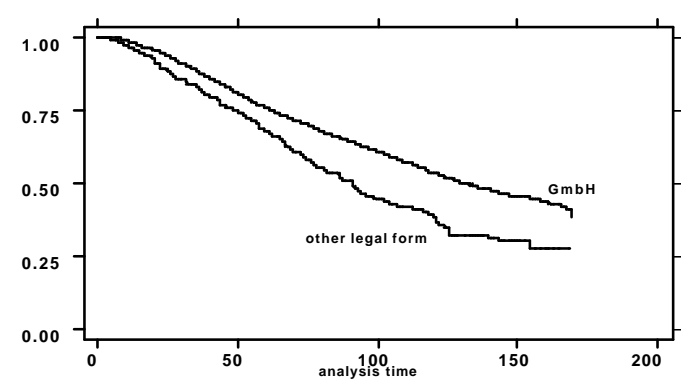

Fig. 3.5 Survival estimates, by legal form of start-up

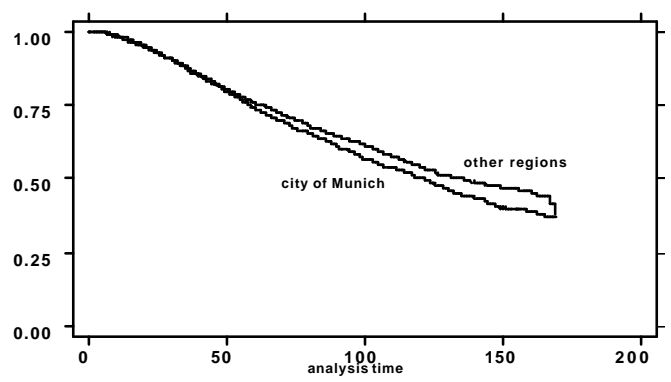

Fig. 3.7 Survival estimates, city of Munich vs. other regions

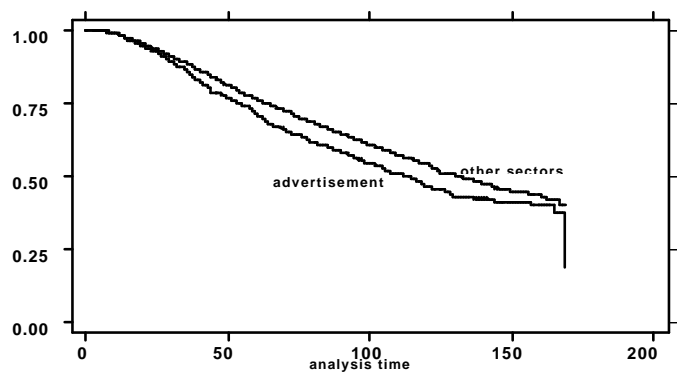

Fig. 3.9 Survival estimates, by advertisement vs. other sectors 
Furthermore it is remarkable that the probability to survive a certain number of months is below average for the sectors „Pharmaceutical Products“ (24.4) and „Advertisement“ (74.4) (Fig. 3.8. and 3.9.), here the exit rate was very high from the mid 90's onwards. For the sectors "Engineering, Scientific and Research, etc. Instruments,“" (33.2) and "Research and Development Laboratories" (73) (Fig. 3.10. and 3.11.) survival rates clearly above average were yielded.

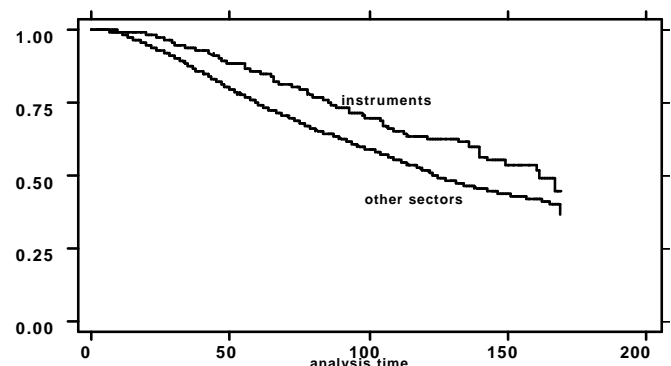

Fig. 3.10 Survival estimates, by instruments vs. other sectors

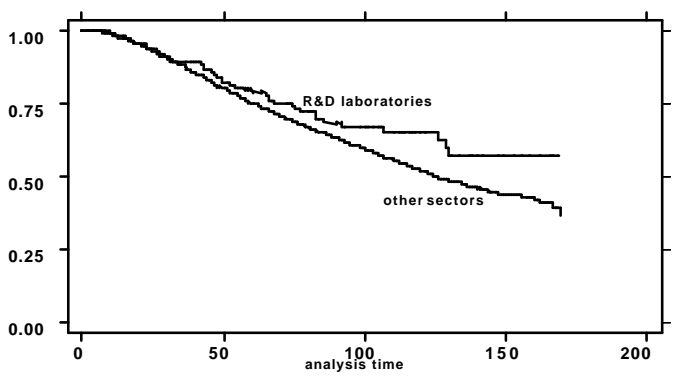

Fig. 3.11 Survival estimates, by $R \& D$ laboratories vs. other sectors

\subsection{Determinants of Survival and Exit of Start-up Companies}

One of the stylized facts regarding the dynamics of industries that has emerged from empirical studies is that the survival rates of firms are positively related both to establishment size and age (e.g. Evans (1987), Phillips and Kirchoff (1989), Audretsch (1991)). Additional to these results the purpose of our study is to ascertain the relative importance of industryspecific variables and the characteristics of the region in explaining the time period between firm birth and its disappearance from economic activity.

Based on our data set a hazard duration function for the start-up companies in the high-tech industry in Upper Bavaria is estimated and then compared between the manufacturing and the service sector. The most important figure in the analysis of duration is the length of time that elapses from the beginning of some event (,entry“) until its end (,exit“) or until the measurement is taken, which may precede termination. The hazard rate $\lambda(t)$ is the rate at which spells are completed after duration $\mathrm{t}$, given that they last at least until $\mathrm{t}$. 
Cox's (1972) approach to the proportional hazard model is a popular method of analyzing the effect of covariates on the hazard rate. The model specifies that

$$
\lambda\left(\mathrm{t}_{\mathrm{i}}\right)=\mathrm{e}^{\beta \mathrm{NX}} \lambda_{0}\left(\mathrm{t}_{\mathrm{i}}\right)
$$

where $\lambda_{0}$ is the „baseline“ hazard, $X$ is a vector of explanatory variables, and $\beta$ is a vector of parameters. The partial likelihood estimator provides a method of estimating $\beta$ without requiring estimation of the baseline hazard $\lambda_{0}$.

A variety of tests suggested that the proportionality assumption embedded in this model was appropriate to our data. A negative/positive coefficient can be interpreted as decreasing/increasing the value of the hazard function and therefore indicates a positive/negative relationship with survival. For a more detailed discussion see Cox (1975) and Kalbfleisch/Prentice (1980).

The variables included in the $\mathrm{X}$ vector are described in Table 3.1.

Table 3.1. Independent Variables

\begin{tabular}{|c|c|}
\hline Variable & Description \\
\hline Branch of Trade & $\begin{array}{l}\text { Dummy variables for each industry: } 11 \text { dummy variables (total) } \\
\text { (respectively } 7 \text { (manufacturing) / } 3 \text { (service)), see Table 2.1. (2.2.) }\end{array}$ \\
\hline Legal Form & 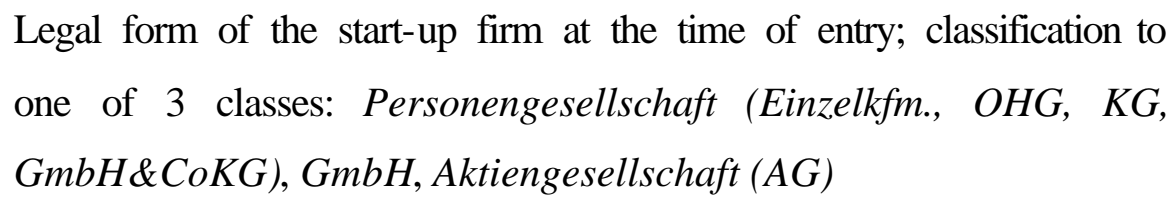 \\
\hline Region & Typ of region: agglomeration area, urbanized area, rural area \\
\hline Start-Up Size & $\begin{array}{l}\text { Employment in the firm at the time of entry; classification to one of } \\
6 \text { size classes }(0-3,4-9,10-19,20-49,50-99,100+\text { employees })\end{array}$ \\
\hline Entry & $\begin{array}{l}\text { Logarithm of the number of new firms in the branch of trade in the } \\
\text { year of entry of the firm }\end{array}$ \\
\hline Industry Size & $\begin{array}{l}\text { Logarithm of the number of all firms in each industry in the year of } \\
\text { entry }\end{array}$ \\
\hline Business Cycle ${ }^{1}$ & $\begin{array}{l}\text { Dummy variable: 1: start-up in cyclical upturn, 0:in cyclical } \\
\text { downturn }\end{array}$ \\
\hline
\end{tabular}

Note: 1) Industrial Output (Mining and manufacturing), seasonally adjusted (see Deutsche Bundesbank (various issues), Statistisches Beiheft zum Monatsbericht 4, ,Saisonbereinigte Wirtschaftszahlen‘, Grafik IV.2) 
Given that firm failure rates vary so extensively across industries, let's now turn our attention to the determinants of the hazard rates and inspect the regression results from the Cox Proportional Hazards Model in Table 3.2.

First, the start-up size of the firms is found to be statistically significantly negatively related to the hazard rate. Only in size classes with a small number of firms the coefficients are not significant because of this. On the whole it can be said that the larger the firm's startup size the lower the risk of failure.

Second, the t-ratios of the coefficients for the variable rural area measuring the characteristics of the region are statistically significant at the 95 percent level in the manufacturing sector and in all industries. The effect of settlement in a rural area (referred to agglomeration area) increases the risk of failure by 33 percent (manufacturing sector) and 14 percent (total). Third, the hypothesis that the legal form of the limited company ( $\mathrm{GmbH})$ (referred to partnerships) reduces the risk of exit can be confirmed: On average for all branches the hazard rate for the "GmbH" is about $34 \%$ lower. Fourth, the t-ratios of the variable entry show no statistically significant result, the variable industry size is statistically significant at the 95 percent level in all industries, in the manufacturing and the service sector (e. g. for the manufacturing sector a one percental change in the number of existing firms in the industry increases the hazard rate by about $0.4 \%$ ).

Finally, our hypothesis that the exposure of new firms to risk tends to be greater in cyclical downturns can only be confirmed at the 95 (90) percent level of significance by altering the dummy variable with a lead of three months in the service sector (in all industries). 
Table 3.2. Regression results from the Proportional Hazards Model ${ }^{\mathrm{a}}$

\begin{tabular}{|c|c|c|c|}
\hline Independent Variables & Total & Manufacturing & Service \\
\hline Branch of Trade & 11 Industry Dummies ${ }^{1}$ & 7 Industry Dummie s ${ }^{1}$ & 3 Industry Dummies \\
\hline Legal Form & \multicolumn{3}{|c|}{ Reference „Personengesellschaft“ } \\
\hline \multirow[t]{2}{*}{$\mathrm{GmbH}$} & 0.659 & 0.616 & 0.660 \\
\hline & $(-5.739)^{* *}$ & $(-2.987) * *$ & $(-5.094)^{* *}$ \\
\hline \multirow[t]{2}{*}{$\mathrm{AG}$} & 1.315 & 0.877 & 1.441 \\
\hline & $(1.295)$ & $(-0.294)$ & $(1.514)$ \\
\hline Region & \multicolumn{3}{|c|}{ Reference „Agglomeration area“ } \\
\hline \multirow[t]{2}{*}{ Urbanized area } & 1.043 & 0.916 & 1.073 \\
\hline & $(0.391)$ & $(-0.285)$ & $(0.606)$ \\
\hline \multirow[t]{2}{*}{ Rural area } & 1.140 & 1.332 & 1.101 \\
\hline & $(2.318)^{* *}$ & $(2.254)^{* *}$ & $(1.510)$ \\
\hline Start-Up Size & \multicolumn{3}{|c|}{ Reference „Size (0-3) } \\
\hline \multirow[t]{2}{*}{ Size (4-9) } & 0.663 & 0.545 & 0.700 \\
\hline & $(-6.034)^{* *}$ & $(-4.104)^{* *}$ & $(-4.666) * *$ \\
\hline \multirow[t]{2}{*}{ Size (10-19) } & 0.574 & 0.505 & 0.596 \\
\hline & $(-4.791)^{* *}$ & $(-2.699) * *$ & $(-3.967)^{* *}$ \\
\hline \multirow[t]{2}{*}{ Size (20-49) } & 0.769 & 0.606 & 0.851 \\
\hline & $(-1.940)^{*}$ & $(-2.168)^{* *}$ & $(-0.967)$ \\
\hline \multirow[t]{2}{*}{ Size (50-99) } & 0.790 & 0.487 & 1.098 \\
\hline & $(-1.060)$ & $(-1.862)^{*}$ & $(0.345)$ \\
\hline \multirow[t]{2}{*}{ Size $(100+)$} & 0.503 & 0.439 & 0.552 \\
\hline & $(-3.574)^{* *}$ & $(-2.774)^{* *}$ & $(-2.344)^{* *}$ \\
\hline \multirow[t]{2}{*}{ Entry $^{2}$} & 1.154 & 1.591 & 1.042 \\
\hline & $(0.604)$ & $(1.161)$ & $(0.127)$ \\
\hline \multirow[t]{2}{*}{ Industry Size ${ }^{2}$} & 11.129 & 39.305 & 9.847 \\
\hline & $(7.066)^{* *}$ & $(4.040)^{* *}$ & $(5.533)^{* *}$ \\
\hline \multirow[t]{2}{*}{ Business Cycle ${ }^{3}$} & 0.991 & 0.790 & 1.033 \\
\hline & $(-0.148)$ & $(-1.467)$ & $(0.467)$ \\
\hline Number of observations & 7738 & 1150 & 6588 \\
\hline LR O & 283.77 & 111.26 & 177.62 \\
\hline Log of likelihood & -19333.25 & -2446.79 & -15823.23 \\
\hline
\end{tabular}

Note: ${ }^{\mathrm{a}}$ Exponentiated coefficients/hazard ratios are displayed. T-statistics in parantheses.

* / ** Statistically significant at 90 / 95 percent level of confidence, two-tailed test. 
1) Industry Dummies statistically significant at the 95 percent level of significance.

2) Hazard ratios of the logarithm of the number of new (all) firms, see Table 3.1.

3) Altering the dummy variable with a lead of three months the coefficient becomes statistically significant at the 90 (total) / 95 (service sector) percent level of significance.

While the results of this study confirm a lot of general findings of other authors (see e.g. Mahmood (1992), Mata and Portugal (1994), Audretsch and Mahmood (1995)), they also point to the importance of establishment-specific, industry-specific and regional characteristics in shaping the post-entry performance of businesses.

\section{Interfirm Collaboration, Innovation Activity and Growth of Start-Up Companies}

\subsection{The survey}

All firms in the selected industries of the manufacturing sector as well as on average 10 percent of firms in the above mentioned service industries received a postal questionnaire asking information about characteristics of the enterprise, firm activity and foundation, cooperations, networks of cooperation and location factors as well as innovation activities.

182 of altogether 1080 questionnaires returned answered and suitable for the analyses, which is a very good response rate of about 17 percent. The answers of altogether 17 personally interviewed entrepreneures have not been used in the analyses following in chapter 4.2 and 4.3 , but still support the results therein contained. The separation of the responses according to industries, regions and size of employment supports our assumption, that the results of the survey are representative.

More than two third of the interviewed companies in manufacturing and more than four fifth in the service sector are settled in the region of Munich. The technologically particularly strong sectors „Pharmaceutical Products“ and „Surgical, Medical and Dental Instruments“, „Computer and Data Processing Services“ and „Research and Development Laboratories“ are 
represented in Munich above average. According to the date of foundation many firms of the sectors „Pharmaceutical Products“ and „Surgical, Medical and Dental Instruments“ as well as more than 50 percent of the service firms are young enterprises. Firms with the smallest size class (up to one employee) are recorded in our data set only in the region of Munich, firms founded before 1985 are represented far below average in the region of Munich.

Due to the fact that only the allocation of firms to size classes at the time of the formation of the company and of the survey (end of 1998/beginning of 1999) is known, we chose the skipping of size classes (in the 12-digit scale, see p. 5) as a measure of employment growth. It is described e.g. as stagnation, if a firm remained in the same size class or ascended only into the next one. In contrast a high dynamic of employment means, that a company skipped three or more size classes. First of all it has to be mentioned, that almost 50 percent of the firms did not or hardly grew in the manufacturing as well as in the service sector. „Pharmaceutical Products“ and „Engineering, Scientific and Research etc. Instruments“, „Computer and Data Processing Services“ and „Research and Development Laboratories“ grew most, about 50 percent of the firms skipped two ore more size classes.

\subsection{Performance of innovation, collaboration and employment growth}

Based on our data set a probit model is used to specify a relationship between a binary (0/1) dependent variable (no cooperation/cooperation) and a set of covariates, gathered in a vector $\mathrm{X}$ which explains the decision to cooperate with a firm or not. The set of parameters $\beta$ reflects the impact of changes in $\mathrm{X}$ on the probability to cooperate. For a more detailed discussion see, for example, Greene (2000).

The variables included in the $\mathrm{X}$ vector are described in Table 4.1. 
Table 4.1. Independent Variables

\begin{tabular}{|c|c|}
\hline Variable & Description \\
\hline Branch of Trade & Dummy variable: 1 :manufacturing sector , 0 : service sector \\
\hline Age & Age of firm (in years) \\
\hline Region & Type of region: agglomeration area, urbanized area, rural area \\
\hline Size & $\begin{array}{l}\text { Current employment in the firm (end of 1998/beginning of 1999); } \\
\text { classification to one of } 6 \text { size classes, combining the } 12 \text { size classes } \\
\text { of the survey }(0-1,1.5-6,6.5-19,20-99,100-499,500+\text { employees) }\end{array}$ \\
\hline Input & $\begin{array}{l}\text { Share of procurement of goods and services from local suppliers in } \\
\text { South Germany (in percent) }\end{array}$ \\
\hline Output & $\begin{array}{l}\text { Share of sales of goods and services to local customers in South } \\
\text { Germany (in percent) }\end{array}$ \\
\hline Contact A & $\begin{array}{l}\text { Dummy variable: 1: Contact with (former) firm/university/research } \\
\text { institute, 0: none }\end{array}$ \\
\hline Contact B & Dummy variable: 1: Contact with (former) teammate/alumni, 0 : none \\
\hline Experience & $\begin{array}{l}\text { Dummy variable: 1: Entrepreneur has knowledge of the } \\
\text { trade/industry, 0: none }\end{array}$ \\
\hline R\&D dept. & Dummy variable: $1: R \& D$ department, 0 : none. \\
\hline
\end{tabular}

Given that readiness to cooperate or not varies across firms and industries, let's now turn our attention to the determinants of this decision and inspect the regression results (column I) from the Probit Model in Table 4.2.

First, the age of the firm is found to be statistically significantly negatively related to the dependent variable. Younger firms cooperate more often than older ones. Second, the tratio of the coefficient for the variable measuring the size of the firm is statistically significant at the 95 percent level. The effect of a rise in the size class of the firm increases the probability of cooperation by 11 percent. One-man-companies cooperate least. Here, as the interviews indicated as well, not only lacking interest but also time plays a role, which a single person is not able to afford for cooperation activity at the beginning of his business project. In the size classes up to 19 employees the proportion of cooperating firms doubles (from 40 to 80 percent), then it lowers slightly. 
Table 4.2. Regression results from the Probit Model ${ }^{\mathrm{a}}$

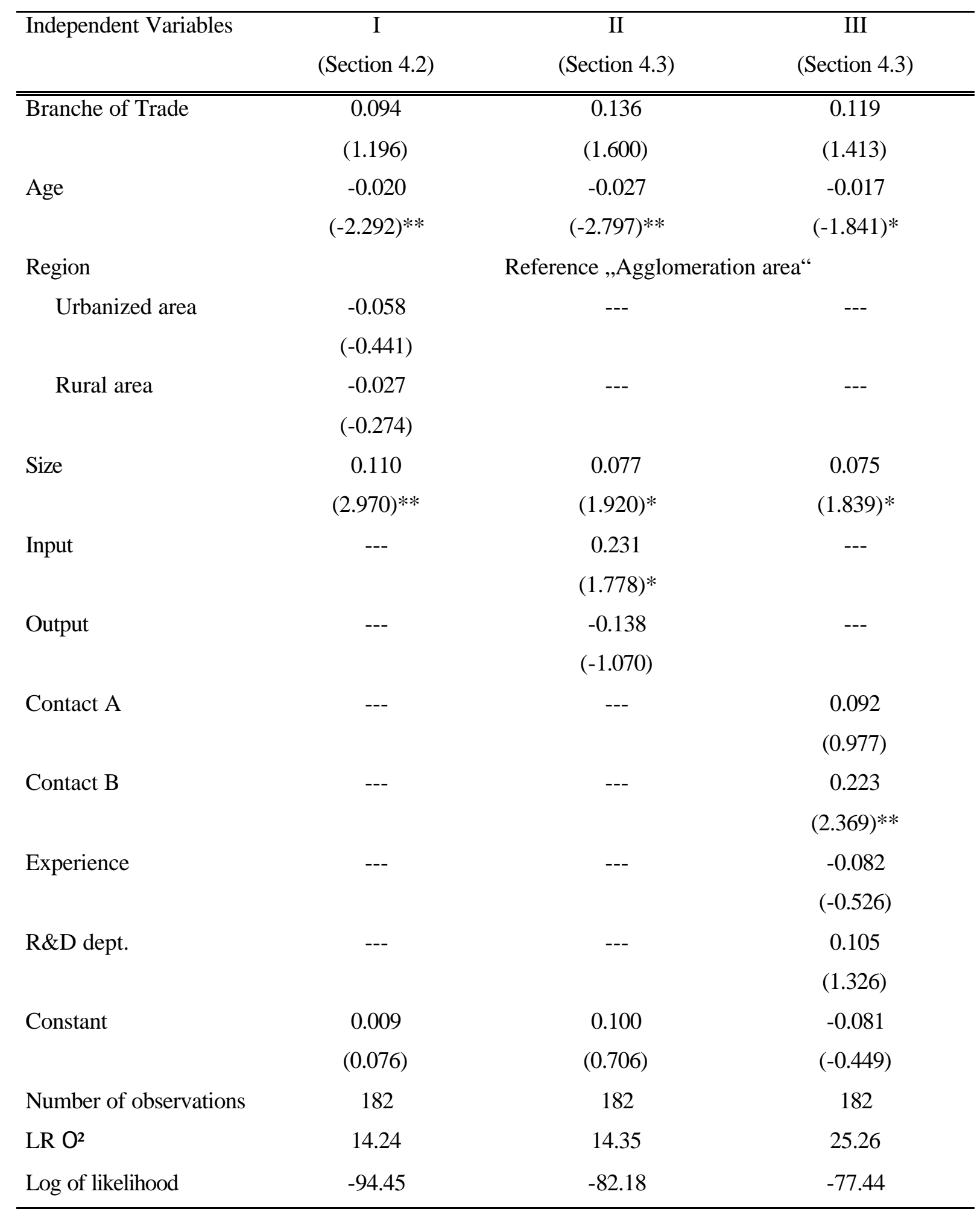

Note: ${ }^{\text {a }}$ Coefficients are the change in probability. T-statistics in parantheses.

* / ** Statistically significant at 90 / 95 percent level of confidence, two-tailed test. 
Finally, the variables region and branch of trade are not statistically significant. However, proportions of cooperating firms far above average can be found in the sectors „Miscellaneous Chemicals”, „Engineering, Scientific and Research etc. Instruments” as well as „Research and Development Laboratories". An analysis of the shares of cooperating firms in different regions shows that there are more cooperations in the agglomeration area than in the rural regions. In the region of Munich the proportion of cooperating firms is clearly greater (72 percent), but also in the southeast of Upper Bavaria (Südostoberbayern) (75 percent) than in the other regions (about 60 percent). This region in the southeast, however, is an exception, which is explainable by a concentration of the chemical industry with a number of connected branch establishments belonging to the same holding.

Additional estimations, which are not included in this article, resulted in a significant relationship between a greater dynamic of employment of firms and the probability of collaboration between firms. Brüderl and Preisendörfer (1998) found empirical confirmation for positive network effects in a study of new business ventures in Upper Bavaria, too. This relationship, however, could be influenced by special features of industries, which could have a positive effect on both growth of employment and cooperation simultaneously. Our analysis shows that the above average cooperating industries „Engineering, Scientific and Research etc. Instruments“ as well as „Research and Development Laboratories“ have an employment growth above average as well.

Likewise the growth of employment in a sector is the larger, the more companies executed product innovations. To that extent it is not surprising, that the sectors with the greatest share of innovating firms are also those with the greatest dynamic of employment. The proportion of the companies with innovations rises with their age. Since companies in the high-tech industries were founded generally with product innovations, it is not surprising, that the product innovation activity is less in young firms compared to old companies. The size class of employment has no influence on the range of innovation activity. In the manufacturing sector he portion of product innovations is clearly greater than that of process innovations, in the service sector - with exception of the sectors „Computer and Data Processing Services“ and „Research and Development Laboratories“ - it is the other way round.

The results don't give any hints, that a dependency between cooperation and innovation activity exists. In so far no innovation networks between companies can be detected. This conclusion is confirmed by the personal interviews with entrepreneurs, that did not recognize a (direct) relationship between their innovation activities and cooperations in R\&D. The proportion of companies with innovations among cooperating firms is not greater than among 
non-cooperating firms. Our investigation doesn't find any hints for relations ,from the local ,milieu“ to innovation through cooperation networks", either, as it is represented by a group of authors around R. Camagni - Groupe de Recherche Européen sur les Milieux Innovateure, GREMI - (Camagni 1991). Our results confirm scepticism expressed in other papers due to the importance of networks (Hellmer et al. 1999).

\subsection{Cooperating partner and form of cooperation}

The interviewed companies cooperate very strongly in production, mostly with firms with a complementary program of production, but also cooperation in research and development is mentioned by more than half of the firms (see Table 4.3.). Cooperations predominantly with universities take place in $R \& D$, this relation is greatest regarding the smallest firms.

Table 4.3. Size classes of employment and cooperation partner

\begin{tabular}{|c|c|c|c|c|c|c|c|c|}
\hline \multirow[b]{3}{*}{$\begin{array}{l}\text { Size } \\
\text { class }\end{array}$} & \multirow[b]{3}{*}{$\begin{array}{c}\text { in } \\
\text { total }\end{array}$} & \multicolumn{7}{|c|}{ Cooperation (in \%) } \\
\hline & & \multicolumn{2}{|r|}{ Thereof } & \multirow[b]{2}{*}{ Distribution } & \multirow[b]{2}{*}{ Marketing } & \multirow[b]{2}{*}{ Production } & \multicolumn{2}{|c|}{ Thereof } \\
\hline & & $\mathrm{R} \& \mathrm{D}$ & $\begin{array}{c}\text { uni- } \\
\text { versity }\end{array}$ & & & & $\begin{array}{l}\text { Comple- } \\
\text { mentary } \\
\text { production }\end{array}$ & $\begin{array}{l}\text { Bottleneck } \\
\text { production }\end{array}$ \\
\hline 1 & 10 & 40.0 & 75.0 & 30.0 & 20.0 & 10.0 & 0.00 & 0.00 \\
\hline 2 & 57 & 54.4 & 58.1 & 40.4 & 19.3 & 59.6 & 82.4 & 26.5 \\
\hline 3 & 58 & 62.1 & 52.8 & 48.3 & 31.0 & 60.3 & 91.4 & 31.4 \\
\hline 4 & 43 & 74.4 & 59.4 & 27.9 & 16.3 & 65.1 & 82.1 & 25.0 \\
\hline 5 & 9 & 55.6 & 80.0 & 33.3 & 0.00 & 77.8 & 100.0 & 42.9 \\
\hline 6 & 5 & 80.0 & 50.0 & 100.0 & 40.0 & 80.0 & 100.0 & 25.0 \\
\hline
\end{tabular}

Cooperations with suppliers from the manufacturing and service sector are in nearly all industries at least as high as, often even higher than the cooperation with the customers, with exception of „Pharmaceutical Products“. Already Oakey (1984) had found in his study that input-output linkages of high technology firms were generally large. The importance of local customers was low (p. 83). In our study nearness to ancillary industries, to service firms, and 
to research and development is regarded as very important by nearly half of the firms, intimacy to customers in only one third of all cases. Our estimations of the Probit Model in Table 4.2. (column II and III) confirm these results of our descriptive analysis: column II shows that input-linkages within South Germany are statistically significant at the 90 percent level, but output-linkages are not significant. An infinitesimal change of the firms' inputlinkages lead to a 23 percent increase in the probability of cooperation. ${ }^{2}$

Table 4.2., column III, indicates that cooperation generally depends on firm's age and size as well as contacts with former teammates or alumni. The existence of an own R\&D department or entrepreneur's knowledge of the trade/industry is not statistically significant. Links between companies and centres of research are analysed in several studies, most of them with the result that there is (mostly local) collaboration (see Prevezer 1995, Audretsch and Stephan 1996, Swann 1998). In our study we find that cooperation with universities - a specific type of R\&D cooperation - are particularly strongly cultivated in the sectors „Pharmaceutical Products“, „Surgical, Medical and Dental Instruments“ and „Research and Development Laboratories“. This last sector comprises most of the biotechnology industry. Regarding both firm size and sector allocation this result is not surprising, since a high percentage of these new enterprises develops out of universities or research institutes. Additional regression results verify these observations. In the cooperation with universities firm's age or size are no longer statistically significant, but the existence of an own R\&D department and contacts to the university or the professorate are statistically significant at the 90 resp. 95 percent level. A change of the dummy variable (contact with (former) teammate/alumni) increases the probability of cooperation by 22 percent. In this context it is to be mentioned that additional estimations of other types of cooperation (e.g. distribution, marketing, production) led to no universally valid results.

\footnotetext{
${ }^{2}$ Among the cooperating companies a location of the partner in Munich/Upper Bavaria is named as important by more than two third, a location in immediate neighbourhood, however, only by a quarter. These answers are absolutly comprehensible, if one considers, that the preferred form of cooperation for 80 percent of all firms is a personal collaboration based on confidence, whereas a cooperation in a common project is like a loose informal contact preferred by about 60 percent. If the cooperation is based on long-term written contracts (about 60 percent), the rights and obligations, and above all the allocation of the advantages of the cooperation, are usually laid down in detail.
} 


\section{Conclusions}

In our paper the analyses of an extensive amount of data about start-ups and survival of firms in high-tech industries are connected with the results of a questioning of some of these firms to their innovative and cooparative behavior and the growth of employment.

Our analysis of entry and exit and of the survival of firms in high-tech industries leads first to the important result, that the hypotheses about differences between various industries in the duration of life of new firms and about the importance of the region of location for the probability of survival are confirmed. Much more enterprises are founded in the service sector than in manufacturing, but also many more of these start-ups die. The differences can already be explained with the differences in the necessary capital endowment, but furthermore it is to be noted that new products are developed particularly in the service sector and it is therefore attempted with many new foundations by trial and error, to find the „exact" niche in the market. The turnover of new firms is much higher in the conurbation of Munich than in rural regions. The probable firms' life duration in agglomeration areas is in total greater than in rural areas, the firms in the city of Munich live clearly shorter, the ones in the close surroundings of Munich clearly longer than in the rest of Upper Bavaria. The high costs resulting from the location in the center of a conurbation are surely a reason for this difference, the higher proportion of service firms in the city with a lower average probability of survival than start-ups in manufacturing is another.

The results of the survival analysis are being substantiated with an analysis of the determinants on the hazard rates of firms. Additionally hypotheses are confirmed, that a larger number of employees at the time of foundation and the legal form of the limited company $(\mathrm{GmbH})($ compared with partnerships (Personengesellschaften)) reduce the risk of exit.

The growth of employment in firms shows a similar sectoral and regional differentation like life duration. Companies in particularly dynamically growing industries, like engineering, scientific and research etc. instruments (33.2) and research and development laboratories (73) have a duration of life far above the average. Pharmaceutics are an exception in that way, that this sector, according to the answers of the interviewed firms, has a high dynamic in employment, but the probability of survival of these firms is on an average clearly lower than in other industries, especially in manufacturing. This results from the fact that our survey 
cannot register the particularly many exits in this industry from the mid nineties on. Only the surviving firms developed dynamically.

Cooperation is a form of organization between market and firm hierarchy and consists of ,relationships between firms (and other organizations), which are more than just spontaneous interchange relationships in the sense of buy/sale (arm's length transactions) ..." (Sydow 1992). It has been detected by us in different forms. But nevertheless rivaly still dominates and cooperation between enterprises are predominantly laid down in precise written contracts. Our hypothesis, that cooperations between smallest firms should be more frequent than between greater firms, was not confirmed. The opposite is the fact, because smallest entrepreneurs see themselves unable to run time-consuming negotiations, which - in their opinion - are inevitable in cooperations with unknown other enterprises to protect their knowhow contribution (see for similar research results: Malecki and Tootle 1996)).

The survey found, that sectors with a greater proportion of cooperating firms, e.g. the sectors engineering, scientific and research etc. instruments and research and development laboratories, have a greater growth. The innovation activities, however, do hardly differ between the analysed high-tech industries. The questioning confirmed the hypothesis, that more innovations lead to a greater dynamic of employment, but there is obviously no context between cooperation and innovation activities. Our firm interviews did neither give any hints, that cooperations - apart from exceptions - are used to solve concrete technological problems nor that cooperating entrepreneurs generally expect a faster growth or more innovations. Cooperations between start-up firms can rather be interpreted as a kind of mutual assistance, which results predominantly from personal contacts and in form of loose informal contacts. In the sector of $R \& D$, where cooperations are particularly frequent, they refer predominantly to the cooperation with universities, and again personal relationships from the graduation and research assistance time of the entrepreneurs play a significant role. These personal networks, particularly in the sector of research and development, are the crucial reason for the higher proportion of cooperating companies in the region of Munich as well.

An important result of our work is thus also that cooperation networks formed with certain goals hardly exist. The cooperation form, which developed from the environment of entrepreneurs and according to specific sector conditions, should not be treated as equivalent to that type of innovation network, which is described as catalyzer of regional development in literature (Camagni 1991) and for which rational means of control are supposed. 


\section{Annex}

Table A1 Characteristics of the planning regions

\begin{tabular}{|c|c|c|c|c|}
\hline & $\begin{array}{c}\text { ROR 1 } \\
\text { Ingolstadt }\end{array}$ & $\begin{array}{c}\text { ROR } 2 \\
\text { München }\end{array}$ & $\begin{array}{c}\text { ROR } 3 \\
\text { Oberland }\end{array}$ & $\begin{array}{c}\text { ROR } 4 \\
\text { Südost- } \\
\text { oberbayern }\end{array}$ \\
\hline Typ of region 1997 & $\begin{array}{c}\text { Urbanized } \\
\text { area }\end{array}$ & $\begin{array}{c}\text { Agglomeration } \\
\text { area }\end{array}$ & rural area & rural area \\
\hline Population 1996 in 1000 & 420.4 & 2399.9 & 408.9 & 762.4 \\
\hline Employees 96 in 1000 & 132.4 & 992.3 & 118.4 & 235.5 \\
\hline \multicolumn{5}{|l|}{ Density of population } \\
\hline 1990 & 136 & 421 & 98 & 136 \\
\hline 1996 & 148 & 436 & 103 & 146 \\
\hline \multicolumn{5}{|l|}{ Secondary sector } \\
\hline 1996 , in \% & 54.7 & 29.7 & 40.6 & 46.6 \\
\hline Growth 1990-96, in \% & -6.7 & -18.4 & -5.1 & -5.4 \\
\hline \multicolumn{5}{|l|}{ Tertiary sector } \\
\hline 1996 , in \% & 44.3 & 69.6 & 58.0 & 52.3 \\
\hline Growth $1990-96$, in \% & 21.9 & 9.4 & 10.1 & 15.1 \\
\hline \multicolumn{5}{|l|}{ Highly qualified } \\
\hline 1996 , in \% & 5.3 & 13.5 & 4.4 & 4.6 \\
\hline Growth $1989-96$, in \% & 43.2 & 25.0 & 33.3 & 31.4 \\
\hline
\end{tabular}

Source:Federal Research Institute for Regional Geography and Regional Planning (BfLR) 
Table A2 Entry/Exit of start-up firms in the high-technology sectors 1985-1998

\begin{tabular}{ccccc||cc}
\hline \multicolumn{1}{c}{ Entry } & \multicolumn{2}{c}{ Exit } & \multicolumn{2}{c}{ Entry/Exit } \\
& Services & Manufact. & Services & Manufact. & Services & Manufact. \\
\hline \hline ROR 1 & & & & & \\
per population & 0.67 & 0.11 & 0.19 & 0.026 & 3.5 & 4.1 \\
per employment & 2.11 & 0.34 & 0.60 & 0.083 & & \\
ROR 2 & & & & & 3.0 \\
per population & 2.25 & 0.37 & 0.67 & 0.12 & \\
per employment & 5.45 & 0.90 & 1.63 & 0.30 & & \\
ROR 3 & & & & & \\
per population & 0.89 & 0.20 & 0.27 & 0.071 & 3.3 & \\
per employment & 3.08 & 0.70 & 0.92 & 0.25 & & \\
ROR 4 & & & & & \\
per population & 0.78 & 0.18 & 0.25 & 0.068 & 3.1 & \\
per employment & 2.51 & 0.58 & 0.81 & 0.22 & & \\
\hline
\end{tabular}

Table A3 Number of firm entries, exits and stock in the high-tech industries of the manufacturing sector in Upper Bavaria and the region of Munich (ROR 2)

\begin{tabular}{|c|c|c|c|c|c|c|c|c|}
\hline & \multicolumn{4}{|c|}{ Upper Bavaria } & \multicolumn{4}{|c|}{ ROR 2 (Munich) } \\
\hline & Entry & $\begin{array}{l}\text { Exit new } \\
\text { firms }\end{array}$ & $\begin{array}{c}\text { exit old } \\
\text { firms }\end{array}$ & Stock & entry & $\begin{array}{c}\text { exit new } \\
\text { firms }\end{array}$ & $\begin{array}{c}\text { exit old } \\
\text { firms }\end{array}$ & Stock \\
\hline pre 1985 & & & & 1023 & & & & 821 \\
\hline 1985 & 93 & 1 & 3 & 1112 & 80 & 1 & 3 & 897 \\
\hline 1986 & 93 & 0 & 12 & 1193 & 77 & 0 & 11 & 963 \\
\hline 1987 & 90 & 0 & 29 & 1254 & 71 & 0 & 26 & 1008 \\
\hline 1988 & 88 & 11 & 24 & 1307 & 73 & 10 & 21 & 1050 \\
\hline 1989 & 87 & 8 & 14 & 1372 & 62 & 7 & 12 & 1093 \\
\hline 1990 & 100 & 12 & 18 & 1442 & 78 & 7 & 15 & 1149 \\
\hline 1991 & 124 & 18 & 20 & 1528 & 92 & 17 & 15 & 1209 \\
\hline 1992 & 95 & 23 & 26 & 1574 & 73 & 16 & 22 & 1244 \\
\hline 1993 & 55 & 36 & 26 & 1567 & 47 & 26 & 23 & 1242 \\
\hline 1994 & 93 & 40 & 31 & 1589 & 68 & 34 & 26 & 1250 \\
\hline 1995 & 74 & 51 & 41 & 1571 & 48 & 35 & 32 & 1231 \\
\hline 1996 & 56 & 60 & 41 & 1526 & 43 & 46 & 33 & 1195 \\
\hline 1997 & 49 & 63 & 52 & 1460 & 34 & 45 & 45 & 1139 \\
\hline 1998 & 53 & 59 & 39 & 1415 & 39 & 49 & 29 & 1100 \\
\hline Total & 1150 & 382 & 376 & & 885 & 293 & 313 & \\
\hline
\end{tabular}


Table A4 Number of firm entries, exits and stock in the high-tech industries of the service sector in Upper Bavaria and the region of Munich (ROR 2)

\begin{tabular}{lcccccccc}
\hline & \multicolumn{9}{c}{ Upper Bavaria } & & \multicolumn{3}{c}{ ROR 2 (Munich) } \\
& Entry & $\begin{array}{c}\text { Exit new } \\
\text { firms }\end{array}$ & $\begin{array}{c}\text { exit old } \\
\text { firms }\end{array}$ & Stock & entry & $\begin{array}{c}\text { exit new } \\
\text { exit old }\end{array}$ & Stock \\
& & & & & firms & firms \\
\hline \hline pre 1985 & & & & 2606 & & & & 2284 \\
1985 & 306 & 1 & 12 & 2899 & 268 & 1 & 10 & 2541 \\
1986 & 338 & 3 & 52 & 3182 & 291 & 2 & 47 & 2783 \\
1987 & 368 & 18 & 144 & 3388 & 309 & 17 & 126 & 2949 \\
1988 & 357 & 36 & 109 & 3600 & 302 & 32 & 92 & 3127 \\
1989 & 465 & 60 & 92 & 3913 & 381 & 52 & 81 & 3375 \\
1990 & 463 & 95 & 81 & 4200 & 378 & 78 & 69 & 3606 \\
1991 & 470 & 90 & 96 & 4484 & 386 & 76 & 83 & 3833 \\
1992 & 407 & 150 & 103 & 4638 & 323 & 130 & 86 & 3940 \\
1993 & 454 & 193 & 97 & 4802 & 353 & 150 & 82 & 4061 \\
1994 & 455 & 199 & 102 & 4956 & 367 & 143 & 92 & 4193 \\
1995 & 490 & 229 & 90 & 5127 & 400 & 198 & 78 & 4317 \\
1996 & 530 & 248 & 114 & 5295 & 415 & 202 & 102 & 4428 \\
1997 & 680 & 295 & 105 & 5575 & 539 & 229 & 91 & 4647 \\
1998 & 805 & 299 & 75 & 6006 & 646 & 240 & 66 & 4987 \\
Total & 6588 & 1916 & 1272 & & 5358 & 1550 & 1105 & \\
\hline
\end{tabular}

\section{Acknowledgements}

The authors express their appreciation for financial support from Deutsche Forschungsgemeinschaft - German Science Foundation - in Bonn with grant No. FL 290/1-1 and from the Gesellschaft zur Förderung der regionalen und urbanen Strukturforschung Association for the Promotion of Research on Urban and Regional Economic Structure - in Munich, who as sole donators made the research project possible. We are also grateful to the Industrie- und Handelskammer für München und Oberbayern - Munich Chamber of Industry and Commerce - for providing data. We would like to extend our thanks to those who have helped us to produce this study, first of all Stefan Haindl, furthermore Patricia Walter, and Björn Hampe who coded the data or provided assistance in data and word processing and translating. 


\section{References}

Agarwal, R and Gort, M (1996) The Evolution of Markets and Entry, Exit and Survival of Firms. Review of Economics and Statistics 78: 489-497

Audretsch, D B (1991) New-Firm Survival and the Technological Regime. Review of Economics and Statistics 60: 441 - 450

Audretsch, D B and Mahmood, T (1995) New Firm Survival: New Results Using A Hazard Function. Review of Economics and Statistics 77: 97-103

Audretsch, D B and Stephan, P E (1996) Compagny-Scientist Locational Links: The Case of Biotechnology. American Economic Review 86: 641-652

Brüderl, J, Preisendörfer, P and Ziegler, R (1992) Staatliche Gründungs-finanzierung und der Erfolg neugegründeter Betriebe. Industrie- und Handelskammer für München und Oberbayern (Ed). München

Brüderl, J and Preisendörfer, P (1998) Network Support and the Success of Newly Founded Businesses. Small Business Economics 10: 213-225

Camagni, R (Ed) (1991) Innovation Networks: Spatial Perspectives. London

Caves, R E (1998) Industrial Organisation and New Findings on the Turnover and Mobility of Firms. Journal of Economic Literature 36: 1947-1982

Coase, R H (1953) The Nature of the Firm. In: Readings in Price Theory. Stigler, G J, Boulding, K E (Eds). London

Cox, D R (1972) Regression models and life tables (with discussion). Journal of the Royal Statistical Society, Series B 34: 187 - 200

Cox, D R (1975) Partial likelihood. Biometrika 62: 269 - 276

Deutsche Bundesbank (various issues) Statistisches Beiheft zum Monatsbericht 4, Saisonbereinigte Wirtschaftszahlen. Frankfurt: Deutsche Bundesbank

Dunne, T, Roberts, M J and Samuelson, L (1988) Patterns of Firm Entry and Exit in U.S. Manufacturing Industries. RAND Journal of Economics 19: 495-515

Evans, D S (1987) The Relationship between Firm Growth, Size and Age: Estimates for 100 Manufacturing Industries. Journal of Industrial Economics 35: 567 - 581 
Gehrke, B and Grupp, H (1994) Innovationspotential und Hochtechnologie - Technologische Position Deutschlands im internationalen Wettbewerb. Hannover

Greene, W H (2000) Econometric Analysis. New Jersey

Harhoff, D and Steil, F (1997) Die ZEW-Gründungspanels: Konzeptionelle Überlegungen und Analysepotential. In: Unternehmensgründungen - Empirische Analysen für die alten und neuen Bundesländer. Harhoff, D (Ed) Baden-Baden

Hellmer, F, Friese, Chr, Kollros, H and Krumbein, W (1999) Mythos Netzwerke. Berlin

Kalbfleisch, J D and Prentice, R L (1980) The Statistical Analysis of Failure Time Data. New York: John Wiley \& Sons

Kiefer, N M (1988) Economic Duration Data and Hazard Functions. Journal of Economic Literature 26: 646-679

Klein, J P and Moeschberger, M L (1997) Survival Analysis. New York

Mahmood, T (1992) Does the Hazard Rate for New Plants Vary Between Low- and HighTech Industries? Small Business Economics 4: 201-209

Malecki, E J and Tootle, D M (1996) The Role of Networks in Small Firm Competitiveness. International Journal of Technology Management 11: 43-57

Markusen, A R (1985) Profit Cycles, Oligopoly, and Regional Development. Cambridge/Mass

Mata, J and Portugal P (1994) Life Duration Of New Firms. Journal of Industrial Economics 42: $227-245$

Mueller, D C (1991) Entry, Exit, and the Competitive Process. In: Entry and Market Contestability: An International Comparison. Gerosky, P A, Schwalbach, J (Eds). Oxford

Nerlinger, E A (1998) Standorte und Entwicklung junger innovativer Unternehmen Empirische Ergebnisse für Westdeutschland. Baden-Baden

Oakey, R (1984) High Technology Small Firms. London

Phillips, B D and Kirchoff, B A (1989) Formation, Growth and Survival: Small Firm Dynamics in the U.S. Economy. Small Business Economics 1: 65-74

Picot, A, Laub, U D and Schneider, D (1989) Innovative Unternehmens-gründungen. Eine ökonomisch-empirische Analyse. Berlin

Prevezer, M (1997) The Dynamics of Industrial Clustering in Biotechnology. Small Business Economics 9: 255-271 
Schumpeter, J A (1912) Theorie der wirtschaftlichen Entwicklung. Berlin

Stigler, G J (1968) The Organisation of Industry. Homewood Ill

Swann, G-M-P, Prevezer, M and Stout, D (1998) The Dynamics of Industrial Clustering: International Comparisons in Computing and Biotechnology. Oxford

Williamson, O E (1989) Transaction Cost Economics. In: Handbook of Industrial Organisation Vol. 1. Schmalensee, R, Willig, R (Eds). Amsterdam

Williamson, O E (1975) Markets and Hierarchies. New York 


\section{IZA Discussion Papers}
No. Author(s)
270
B. Augurzky
C. M. Schmidt
271
B. Augurzky
C. M. Schmidt
272
C. Belzil
J. Hansen

273

G. Saint-Paul

274

P.J. Pedersen

N. Smith

275

G. S. Epstein

T. Lecker

276

277

B. Amable

D. Gatti

R. Winter-Ebmer

278

T. M. Andersen

279

T. M. Andersen

280

P. Apps

R. Rees

281

G. Saint-Paul

282
J. Albrecht
A. Björklund
S. Vroman

Title

Area

Date

The Evaluation of Community-Based

6

03/01

Interventions: A Monte Carlo Study

The Propensity Score: A Means to An End

6

$03 / 01$

Heterogeneous Returns to Human Capital and

5

03/01

Dynamic Self-Selection

Distribution and Growth in an Economy with

5

03/01

Limited Needs

Unemployment Traps: Do Financial Dis-

3

03/01 incentives Matter?

Multi-Generation Model of Immigrant Earnings:

1

03/01

Theory and Application

The Impact of Product Market Competition on

5

03/01

Employment and Wages

Evaluating an Innovative Redundancy-Retraining

6

03/01

Project: The Austrian Steel Foundation

Welfare Policies, Labour Taxation and Inter-

2

$04 / 01$

national Integration

Product Market Integration, Wage Dispersion

2

04/01 and Unemployment

7

04/01

the Life Cycle

5

04/01

Elites

Is There a Glass Ceiling in Sweden?

5

04/01 

and the Rising Returns to Skill: US and France 1964-2000 
298

P. Telhado Pereira

Returns to Education and Wage Equations
A. Stutzer

R. Lalive

301

J. R. Frick

G. G. Wagner

302

G. S. Epstein

A. Weiss
H. Bonin
G. Abío
E. Berenguer
J. Gil
C. Patxot 
Costs
A. Frederiksen
E. K. Graversen Germany:

Overtime Work, Dual Job Holding and Taxation 

2000 

A. lbourk
B. Maillard
S. Perelman
H. R. Sneessens

The Matching Efficiency of Regional Labour

Markets: A Stochastic Production Frontier

Estimation, France 1990-1995 